\title{
Reality or Pretense? Renouncing Nationality and Organized Hypocrisy of the Sovereignty of Taiwan
}

Isabelle Cheng, University of Portsmouth

\begin{abstract}
Adopting Krasner's thesis of organized hypocrisy, this research examined the institution of sovereignty in regard to the naturalization of migrant spouses in Taiwan. Using migrant spouses as a case study, this article argues that the hypocrisy of Taiwan's sovereignty lies in demanding migrants to renounce their native nationality or cancel their household registration. This demand not only fails to prevent statelessness but also prompts the origin state to recognize or reject Taiwan's sovereignty. The interactions between Taiwan and the origin states of migrant spouses from Japan, Vietnam and China underline the hypocrisy of Taiwan's sovereignty. The more Taiwan insists on migrant spouses renouncing their original nationality, the more this destabilizes Taiwan's sovereignty because of its lack of international recognition.
\end{abstract}

Keywords: sovereignty, organized hypocrisy, nationality, statelessness, household registration, Taiwan 


\section{Introduction}

Challenges to state sovereignty continue and presently, these concerns persist in the light of a transnational and globalized world. Transnational migration-the movement across national borders - is one of the processes that renders national boundaries porous (Chamberlain, 2015). Transnational migration to Taiwan poses a challenge to the state's capacity to control in-bound migration. It is also an ontological contestation of the very existence of its statehood, since Taiwan is not universally recognized as a sovereign state under the official title of the Republic of China (ROC). Focusing on the case of migrant spouses, this paper argues that Taiwan's naturalization laws and its interactions with the origin states of foreign spouses concerning the granting of citizenship is an illustration of the hypocrisy of sovereignty (Krasner, 1999). Seeing the requirement of renunciation as an assertion of Taiwan's challenged sovereignty, this hypocrisy is manifested by Taiwan's flexibility towards Japanese citizens' unavailability of renunciation, in contrast to Taiwan's rigidity towards Vietnamese citizens and its pragmatism of using household registration as a make-believe nationality for Chinese citizens. Hypocrisy is also embedded in the reaction of these origin states, under their One China Policy, to the requirement of renunciation. While Japan objects, Vietnam permits and China facilitates their citizens' acquisition of Taiwan's citizenship.

Since the late 1980s, Taiwan has risen to become a major destination in East Asia for migrant workers as well as migrant spouses. Men and women from Southeast Asia are employed in construction, manufacturing and caregiving which have been shunned by local workers. (). Taiwan, like other destination countries in Asia, including those in the Gulf region, maintains a strict 'guest workers' policy and denies them eligibility for naturalization (Wang, 2011; Lu, 2000;Tseng and Komiya, 2011), a condition which makes Taiwan a 'walled state' (Brown, 
2010). In contrast, naturalization is open to migrant spouses, mostly women (Kawaguchi and Lee, 2012). Pursuing betterment for themselves and their families, migrant wives from China, Vietnam, Indonesia, Thailand, the Philippines, Cambodia and Burma have settled in Taiwan after their marriage and formed a family with Taiwanese citizens.

From 1987 to 2016, a total of 152,817 foreign women, mainly from the abovementioned Southeast Asian countries, as well as 318,338 Mainland Chinese women, resided in Taiwan as spouses of Taiwanese citizens (NIA, 2017). Among them, a total of 115,392 foreign women (including a very small fraction of non-Southeast Asian origins) and 119,147 Chinese women had acquired citizenship (NIA, 2017). Considering the small number of naturalizations that were granted by means other than marriage with Taiwanese citizens (4.34 percent of total naturalizations between 1982 and 2015) (MoI, 2015), migrant wives comprise the overwhelming majority of foreign-born citizens in Taiwan. Under Taiwanese law, naturalization cannot be completed without renunciation of the applicant's native or previous nationality. For the citizens of the People's Republic of China (PRC), given the mutual non-recognition of Taiwan and China for each other's sovereignty, instead of relinquishing their PRC nationality as foreign nationals shall do, they are required to cancel their household registration in China, as a substitute for renunciation..

Given the contested statehood of Taiwan, this paper raises an obvious but rarely asked question: how could Taiwan, whose sovereignty is not universally recognized by the international community, make foreign citizens to lose their original nationality and replace it with a nationality that is only officially recognized by 20 states as of June 2017? This question was brought to the fore by a comment made by a Vietnamese woman I interviewed in 2009 . As she put it, 'the Taiwanese nationality has to be real, otherwise why would I lose my Vietnamese 
nationality to get a fake one?' Given that nationality is the foundation for human dignity (Gross 2001: 851), if the sovereignty of Taiwan is considered non-existent in international politics, how can it have such a significant effect on naturalized foreign nationals? Considering that the state is morally obliged to prevent its citizens from being stateless, how can the origin states of the 115,392 marriage migrants allow them to relinquish their legal bond with their native country? If Taiwan were a 'renegade province' as claimed by the $\mathrm{PRC}$, how can a 'provincial' authority endow 119,147 PRC citizens with ROC citizenship and issue them ROC passports which enable them to travel around the world? These are the puzzles that this research intends to tackle.

To carry out this research which cuts across international politics and transnational migration, it adopts the concept of 'organized hypocrisy' coined by Krasner (1999) about sovereignty. In line with Krasner's argument that it is hypocritical that lacking universal recognition does not prevent Taiwan from developing relationships with other states, this research further argues that hypocrisy is also pronounced by Taiwan's interactions with other states in regard to renunciation. The hypocrisy lies in the critical decisions of how the origin states regard Taiwan's sovereignty and whether they permit or object to their citizens losing their nationality. Hypocrisy is also found in Taiwan's t appropriation of household registration as a replacement for nationality, a practice that is tacitly accepted by the PRC. These findings will deepen our understanding of the limitations of sovereignty as an institution that is morally obliged to protect human dignitys.

Before examining the impact of renunciation, it is necessary to review how the sovereignty of Taiwan is being analyzed from the vantage point of marriage migration. This review is to be followed by a discussion of how sovereignty is diagnosed as 'organized hypocrisy’ by Krasner (1999). 


\section{Sovereignty and marriage migration}

As shown above, the PRC is the largest source of marriage migration to Taiwan. The growing Taiwanese identity and partisan differences between the two major political parties on policies toward China have politicized the issue of marriage migration from China (Chen and $\mathrm{Yu}, 2005)$. . Cheng (2016) points out that, despite democratisation and political reform in the early 1990s, PRC citizens continue to be constitutionally regarded as ROC nationals. The task of defining this confusing status is left to the Act Governing the Relations between People of the Taiwan Area and the Mainland Area promulgated in 1992 (conventionally known as the Cross-Strait Relations Act). The Cross-Strait Relations Act ascertains that they are neither foreign nor domestic but 'special.' Their special status creates a dual track in citizenship legislation (Wu, 2008): while foreign spouses have to relinquish their original nationality to acquire ROC citizenship, Chinese spouses are required to cancel their household registration in China. In the latter case, the household registration signifies the territorial link between Chinese spouses and the state of Taiwan thereby legitimizing their acquisition of citizenship in Taiwan (Cheng, 2016).

Aided by ethnographic insights, Friedman (2015) asserts that research on sovereignty cannot be restricted to its philosophical foundation or institutional specifications. Rather, the effects of sovereignty on migrants' legal status can be created and experienced through mundane interactions between government agents and Chinese spouses at public hearings, orientation courses, street rallies or the administered 'border' erected at the landing ports of Taiwan. Chao (2004, 2005) and Chen (2010) note that the determination of authenticating marriages between couples from mutually hostile regimes underscore the anxieties of the patriarchal state of Taiwan in asserting its contested sovereignty and protecting the porous border that is being transgressed by marriage. 
It is commonly acknowledged that the politicization of marriage migration from China is rooted in the threat posed by the PRC - mainly the denial of Taiwan's sovereignty (Wu, 2008) to the survival of the island nation (Wang, 2011). Although Southeast Asian states also do not recognize Taiwan's sovereignty, they are not seen as posing an imminent threat to Taiwan's legal existence. Being economically more developed, Taiwan views the Southeast Asian countries as sites to lower production costs (Huang, 2006; Hsiao, 2003). The government's Go South policy was an attempt to earn more profits for Taiwanese investments as well as loosening these countries' One China Policy (Peng, 1997; Huang and Liaw, 2012).

Under such circumstances, marriage migration from Southeast Asia is less of a political or is even an apolitical issue. The threat posed by this migration is conceptualized along the line of eugenics, based on the perception by the government and society at large that children born to poor, less educated and non-Chinese-speaking Southeast Asian mothers will erode Taiwan's international competitiveness (NSC, 2006: 61; Kuo, 2011). For this reason, in 2005, Chinese language proficiency (or passing a test on the way of life in Taiwan) became a prerequisite for naturalization in addition to financial adequacy. Other studies also point out that the stress on reproduction and motherhood is a case of biopolitics, which marks the bodies of migrant spouses as an ethnic boundary between the host state and migrant outsiders (Lan, 2008; Chen, 2009; Yuval-Davis and Anthias, 1989: 7). In sum, various studies allude to the selectiveness of Taiwan's sovereignty as embedded in the naturalization legislation, reflecting biases of patriarchy, sexism, nationalism and classism (Wang, 2008, 2011; Sheu, 2007; Tsai, 2011; Yang and Lee, 2009; Cheng, 2013). 
It is interesting to note that no questions have been raised on the sovereignty itself in the context of marriage migration. That is, how can Taiwan, a state that is not widely recognized, require migrant spouses to renounce their original citizenship to acquire Taiwanese citizenship that is not considered 'real' by the international community? Likewise, there have not been sufficient attempts at comparing the different requirements for Chinese and foreign spouses to understand how transnational migration affects the operation of sovereignty. Viewing renunciation as a major 'sovereignty effect' (Friedman, 2015) whereby Taiwan exercises its sovereignty, this research will show how sovereignty as a concept and as an institution is fundamentally hypocritical for its self-contradiction against the responsibility of preventing statelessness. By juxtaposing the different citizenship requirements applied to Chinese and foreign spouses, this article will show the struggles of Taiwan in securing legitimacy for its sovereignty in the international community on the one hand, and the hypocrisy of its sovereignty in its interactions with Japan, Vietnam and China.

To tackle this puzzle, this research employed and modified Krasner's (1999) thesis of 'organized hypocrisy.'

\section{Sovereignty: Organized hypocrisy}

States are endowed with authority to rule over the people in a defined territory and have the power to operate this authority inside and outside the territory. Krasner delineates the meanings of sovereignty into four non-exclusive categories. International legal sovereignty refers to the mutual recognition received and offered by any given state. Westphalian sovereignty addresses the ultimate and inalienable authority of a state for its internal affairs within its territory. 
Domestic sovereignty is the conglomerated power endowed to the government for decisionmaking over public affairs, such as fiscal, economic and environmental policies. Interdependent sovereignty operates in the context of transnational movement of capital, people, ideas, goods and services (Krasner, 1999: 9-25). The former two categories allude to the realm of authority. Domestic sovereignty is concerned about authority and control, while the interdependent sovereignty belongs to the domain of control (Krasner, 1999: 4, 10). Krasner dismisses globalization or transnational movement as forces that can uproot the foundation of international legal sovereignty and Westphalian sovereignty. To him, these challenges mainly test the capability of the state to safeguard its borders, ensure the reception of benefits of transnational movement, manage the consequences of globalisation, and coordinate with other states for all of these tasks. These are the issues that defy the control of the government rather than weaken its authority (Krasner, 1999: 12, 220-223).

Krasner articulates that fundamental challenges are those that cast doubt on the authority of the state's sovereignty. The authority of the state is built on the principles of external recognition and internal supremacy, twin values that are at the core of international legal sovereignty and Westphalian sovereignty, respectively. However, these are the same values where hypocrisy is found; that is, the discrepancy between these normative values and practices, according to Krasner. Krasner cites several examples where hypocrisy is at work. In the realm of international legal sovereignty, the lack of external recognition does not prevent non-recognized states, such as Taiwan, from developing bilateral and multilateral relationships with other states ( Krasner, 1999: 4). Sub-state units, such as Hong Kong in the World Trade Organization, and Ukraine and Belarus in the United Nations during the Cold War, were offered membership to international organizations that otherwise restrict membership to sovereign states ( Krasner, 
1999: 16). As regards to Westphalian sovereignty, rulers of strong states interfere in the domestic affairs of weaker states, or rulers of weaker states allow other states or international organizations to influence their economic, fiscal and social policies. The many 'exceptions' to external recognition and internal supremacy led Krasner to view these violations as 'organized hypocrisy’ ( Krasner, 1999: 9).

Krasner explains that his theorisation of organized hypocrisy adopts an 'actor-oriented' approach and the ruler of the state is the unit of analysis (Krasner, 1999: 43). In geopolitics where material resources are asymmetrically allocated among states, rulers may or may not choose to abide by the principles of external recognition and internal supremacy when they make decision in their foreign or domestic policies. Their decisions are pragmatically constrained by their intention of staying in office and the necessity of satisfying the interests of their constituents. The source of organized hypocrisy derives from the violation of these principles that are held as the essence of sovereignty (Krasner, 1999: 9).

In applying the concept of organized hypocrisy to the issue of renunciation, this research focused on international legal sovereignty and Westphalian sovereignty because renunciation is principally an issue of authority rather than control. It is an issue of Westphalian sovereignty because it contests whether the apparatus of sovereignty can exercise its jurisdiction within its territory on migrants without being compromised or impeded. It is also an issue of international legal sovereignty because renunciation cannot be realized without the permission of the origin state. Given that the state is morally bound to prevent its citizens from becoming stateless, the 
origin state's agreement to renunciation is an expressed opinion of the existence of the state of Taiwan.

Therefore, the unit of analysis in this research is not the ruler but the institution of sovereignty. The ruler's preservation of self-interest is conceptually treated as given while the conglomerated outcome of their foreign policy - the One China Policy and the non-recognition of the statehood of Taiwan - constitutes an external structure that cannot be unilaterally changed by Taiwan. What concerns this research is whether an international legal sovereignty that suffers from limited external recognition prevents Taiwan from receiving the agreement of other states for renunciation and replacing the lost nationality with ROC nationality. This research is also concerned about the operation of Westphalian sovereignty (i.e., a nation-state's sovereignty over its territory and domestic affairs) in Taiwan, and how it exerts its ultimate and inalienable jurisdiction over foreign and PRC citizens. In tendon with research of international law on the anomalies and inconsistencies of nationality theory and legislation stemmed from nonrecognition of sovereignty (Grossman, 2001), the findings of this research will provide an institutional perspective from which to underline the hypocrisy of sovereignty.

In the following section of case study, I used the existing literature in drawing a geopolitical picture of the hypocrisy of Taiwan's sovereignty as shaped by the One China Policy. Against this background, I then used the Legislative Yuan Gazette and news reports to examine how the state of Taiwan executes the renunciation of foreign spouses' native nationality and the cancellation of Chinese spouses' household registration. Restricted by publicly available information, my examination of how foreign governments respond to this requirement concentrated on Japan and Vietnam. The two cases are chosen because they are the largest source countries of migrant spouses from developed (Japan) and developing (Vietnam) countries. 
More importantly, the Taiwanese government openly acknowledges Japan as not recognizing Taiwan's sovereignty, whereas Vietnam is known for receiving a large number of returned spouses who became stateless after renunciation. This research argues that the hypocrisy arising from renunciation is found in two aspects. On the one hand, the state of Taiwan does not acknowledge the inherent contradiction between its demand of renunciation and its responsibility to prevent statelessness. In practice, the co-existence of flexibility and rigidity Taiwan shows to Japan and Vietnam regarding renunciation, and Taiwan's appropriation of household registration as a nationality substitute for PRC immigrants underlie the precariousness of external recognition that is considered pivotal to the existence of sovereignty.

\section{The known story of hypocrisy: Geopolitics and One China Policy}

Although Taiwan is able to maintain links with states around the world, its sovereignty is rendered uncertain because of geopolitical interests pursued by major powers such as China and the US. During the Cold War, the sovereignty of Taiwan, under the official title of ROC, was undermined following the Chinese Civil War (Morello, 1966). It lost its claim of legitimately representing China after the Sino-US rapprochement since 1972. Having secured its legitimacy as the sole representative of China, the PRC ousted the ROC from the UN and other major international organizations. The PRC claims sovereignty over Taiwan and its offshore islands (Gu, 1995) and it maintains that Taiwan is part of China as a renegade province. China ensures that its allies, including Japan, Vietnam, Indonesia and the Philippines, which are the major sources of migrant spouses to Taiwan, adhere to this so-called One China Policy. 
What makes the international legal sovereignty of Taiwan even more fragile is its aspiration for self-determination (Deans, 2001). Since the constitutional reforms that began in the early 1990s, in spite of clinging onto the Civil War legacy of claiming sovereignty over Mainland China, Taiwan has realistically and pragmatically acknowledges that its jurisdiction has been scaled down to the territory that has been under its effective control since 1949, which is the aggregation of Taiwan, Penghu, Jinmen and Mazu (Taiwan proper) (Lee, 1999; Hughes, 1999). In the wake of democratization from the 1990s, the once suppressed indigenous desire for independence rose in popularity and stirred calls for formalizing its de facto and de jure separation from China (Roy, 2003:183-246). Nevertheless, the islanders have yet to reach a national consensus on the ultimate status of the nation-state and until then, Taiwan cannot finalize its legal relationship with the PRC.

The sovereignty of Taiwan, thus, is crippled by liminality. Its anachronistic sovereignty claim over Mainland China is negated by the PRC, questioned by Taiwanese citizens and ignored by most states around the world. On the other hand, in spite of being fully functioning, its concurrent sovereignty claim to Taiwan proper is the reality lived by its citizens and migrants, rejected by the PRC, and not supported by international community (Tucker, 2011). Trapped in this liminality, the island republic is not officially accepted as either the ROC or Taiwan. It does not enjoy the freedom of joining international activities on an equal footing with other sovereign states. Stripped of official status, this self-proclaimed state has to be unofficially represented by sub- or non-state entities in its engagement with other sovereign states and international governmental organizations in areas such as health, fishing, climate change, and sports (Ho, 2006; Chang, 2010; Yang and Chien, 2010; Hsiao and Hsiao, 2011; Huang and Wang, 2013). 
This liminality narrates an already well-known story of how the international legal sovereignty of Taiwan is rendered hypocritical because of geopolitical interests, as argued by Krasner (1999). What has not been fully examined is how its sovereignty functions as a host state of immigration that executes naturalization and renunciation. As explained below, this research will argue that being restrained by these international legal and geopolitical surroundings, the execution of renunciation of Japanese, Vietnamese and Chinese spouses, and the varying interactions between Taiwan and these origin states is another testimony of the hypocrisy of Taiwan's sovereignty.

\section{The lesser known story of hypocrisy: Marriage and nationality}

To grant, deny or deprive a person of nationality used to be seen as solely deriving from the authority of a sovereign state. However, the massive human displacement partly due to statelessness created during the Second World War (Hayden, 2008) resulted in the inclusion of the right to nationality as a human right that is enshrined as Article 15 of the Universal Declaration of Human Rights (Van Waa, 2012). As a fundamental human right, having a nationality is 'a foundation of identity, dignity, justice, peace and security' (Refuge International, as cited by Kingston, 2013: 75-76). Developed along lines of liberal philosophy, the acquisition (other than by birth) or loss of nationality cannot be made without the express consent of the individual. On the other hand, this fundamental right would be meaningless if the state fails to grant nationality or prevent the loss of nationality. Since nationality is a matter of legality as well as morality, the state is morally responsible for preventing statelessness (Van Waas, 2012), as stipulated by the 1954 Convention Relating to the Status of Stateless Persons. 
However, historically, the nationality of women who marry foreigners poses a violation of the fundamental value of free will and potentially leads to statelessness (Scott, 1929; Augustine-Adams, 2002; Studer, 2001). In the past, women who marry foreigners lost their original nationality and adopted the nationality of their husbands. This so-called 'marriage rule' can be found in the ruling of an Argentinian Court in 1897 stipulating that 'When a woman marries a foreigner, she knows that, by her marriage, she becomes a foreigner, and she consents implicitly in the renunciation of her nationality and the acquisition of her husband's' (emphasis added) (Augustus-Adam, 2002: 19). The deprivation of her original nationality is a consequence for her 'defection' of her nation (Epstein, 1978: 106), while adopting the husband's nationality is upheld on the 'principle of family unity,' which is mainly to ensure patrilineal genealogy, regarded as the foundation of national belonging (De Hart, 2006a, 2006b). An obvious loophole to the idea of 'family unity' is that if a foreign wife did not obtain the nationality of her husband, she is rendered stateless (Feinberg, 2006). To prevent statelessness, it is necessary to separate marriage from nationality. This was achieved internationally by the 1957 Convention on the Nationality of Married Women. With the removal of the marriage rule, spouses, regardless of their sex, are offered pathways for naturalization (mostly requiring a shorter duration of residency for eligibility), mostly to facilitate the right of the couple and the children to family reunion.

\section{Permit to renounce or not to}

As mentioned earlier, from 1987 to 2016 , more than 433,000 foreign wives have resided in Taiwan. Table 1 shows that marriage migration to Taiwan overwhelmingly involves women and mostly those from Southeast Asia. From 1999 to 2015, a total of 101,783 wives from Southeast Asia had acquired ROC nationality, compared with 160 wives from Japan, South Korea, 
Singapore, the US and Germany (Table 1). Ethnographic findings indicate that ROC nationality is deemed not only desirable but also necessary by Southeast Asian women for employment, social security, non-conditional residency in Taiwan and a sense of equality, inclusion and respect (Cheng, 2013; 2017a). In contrast, a qualitative study of Japanese wives suggests that ROC nationality was not viewed as essential to their life in Taiwan (Hsiao, 2010). Therefore, while ROC sovereignty is universally applied to all foreign spouses, its actual impact on the living conditions of women varies according to the women's ethnicity and socio-economic status.

Table 1. Number of foreign spouses who acquired ROC nationality: 1999-2015.

\begin{tabular}{|l|r|r|r|}
\hline Country of origin & Men & Women & Total \\
\hline Vietnam & 138 & 69,721 & 69,859 \\
\hline Indonesia & 210 & 19,414 & 19,624 \\
\hline Cambodia & 1 & 4,509 & 4,510 \\
\hline The Philippines & 167 & 4,208 & 4,375 \\
\hline Myanmar & 183 & 1,781 & 1,964 \\
\hline Thailand & 14 & 1,208 & 1,222 \\
\hline Malaysia & 48 & 181 & 229 \\
\hline Japan & 13 & 82 & 105 \\
\hline Korea & 8 & 8 & 77 \\
\hline Singapore & 2 & 5 & 7 \\
\hline US & 0 & 1 & 1 \\
\hline Germany & & & \\
\hline
\end{tabular}




\begin{tabular}{|l|r|r|r|}
\hline Others & 326 & 142 & 468 \\
\hline Stateless/Unspecified & 10 & 105 & 115 \\
\hline Total & 1,143 & 101,429 & 102,572 \\
\hline
\end{tabular}

Source: MoI, 2015.

Taiwan, however, has not kept abreast with the global trend in regard to the naturalization of foreign spouses and the prevention of statelessness. It implemented the Nationality Law that was promulgated in China in 1929, and after 1949, Taiwan executed the marriage rule and the principle of family unity: foreign wives were automatically granted ROC nationality upon marriage, after they relinquished their nationality of descent. Although renunciation was not required by law, administrative decrees included it as a prerequisite to ROC nationality (Tseng, 1999: 49; Wang, 2011:182). In 2000, the Nationality Law was amended for the very first time after being in effect for 71 years. One of the significant changes made was to abolish the marriage rule and regard marriage as one of several grounds for naturalization. The law now considers marriage a privileged status qualifying foreign spouses an easier access to nationality so as to protect citizens' right to family life (Tsai, 2008). nevertheless, the law also makes renunciation a precondition for all applicants for naturalization, in spite of controversially allowing dual nationality for Taiwanese birth citizens (LY, 1998a: 201, 206). Renunciation makes foreign spouses vulnerable to statelessness because the legality of their naturalization is entirely hinged upon the validity of their marriage.

As stated above, renunciation is a site where the authority of Westphalian and international legal sovereignty is exerted. The Nationality Law of Taiwan stipulates that a 
foreign spouse, regardless of sex, may be eligible for naturalization if he or she is of good character, is financially sufficient, has continuously resided in Taiwan for a minimum of three consecutive years, acquires Chinese language ability or passes the test of the knowledge of the way of life in Taiwan (Article 3,4) and has relinquished his/her nationality of descent (Article 9). Before the Nationality Law was amended in December 2016, after an applicant submitted to the government his/her renunciation certification, the applicant would be issued a 'quasinaturalization' certificate. On this 'quasi-naturalization' status, the applicant would have to wait from one to five years, depending on the actual days of his/her residency in Taiwan, before receiving ROC nationality (Article 4, Notice for the Supporting Documents Required for the Applications of Entry, Residency, and Settlement of Nationals without Household Registration in Taiwan; Tsai, 2008: 5; LY, 2016: 37). During this 'in-between' period, the applicant was technically made stateless. If the marriage dissolved during this period because of divorce or death of his/her Taiwanese spouse, the applicant not only became stateless but might also face expulsion because the cessation of the marriage nullified the legality of his/her residency and naturalization.

However, exception can be made to the requirement of renunciation. Article 9 stipulates that if a foreign national alleges that renunciation cannot be obtained due to causes that are not attributable to the individual, and this has been validated by the Taiwanese government, then renunciation may be waived. This article underlines that the loss of nationality is a sovereign decision made together by Taiwan and the state of origin. As discussed below, this joint decision is a strategic site where the hypocrisy of sovereignty is located. Japan rejects the request of renunciation made by its citizens because of its non-recognition of the statehood of Taiwan. In 
2010, the number of registered stateless persons in Japan amounted to 1,234, including persons of ROC nationality whose statelessness resulted from Japan's adoption of the One China Policy and the change in its diplomatic recognition from the ROC to the PRC in 1972 (Chen, 2012). In November 1998, when the draft bill of the Immigration Act was under parliamentary review, the government stated that Japan does not allow dual nationality, thus Japanese citizens could not acquire another nationality without prior renunciation of Japanese nationality. Most critically, the Taiwanese government confirmed that if the acquired nationality was of a state that was not recognized by Japan, such as Taiwan, the Japanese government would overrule such renunciation in order to prevent statelessness (LY, 1998a: 190; LY, 1998b: 298, 304). Thus, the Taiwanese government has acknowledged Japan's non-recognition of Taiwan's international legal and Westphalian sovereignty. In response Taiwan exempts Japanese spouses from having to renounce their Japanese citizenship. Article 9 of Taiwan's Nationality Law (permitting naturalization candidates to retain native nationality in case renunciation is unattainable) was specifically promulgated to ease the difficulty encountered by Japanese citizens (Hsiao, 2010:25). By invoking this exemption, a total of 22 Japanese spouses received ROC nationality without losing their Japanese nationality (Liberty Times, 2007).

Taiwan's accommodation toward Japan's policy is a stark contrast to its strict enforcement of renunciation on Vietnamese, Filipino and Indonesian women's application for naturalization. There are no publicly available records ascertaining the response of these three states to Taiwan's demand of renunciation. However, the very fact that they permitted their citizens to renounce can be interpreted as that they do not expressly dispute Taiwan's international legal sovereignty. This is perplexing, considering that all of them have adopted the One China Policy and have reaffirmed their non-recognition of Taiwan's statehood in several 
diplomatic incidents.. (Xinhua News Agency, 2002; BBC Monitoring International Reports 2006; the China Post, 2011) Furthermore, all of them have had experience in accommodating in their territory a significant number of de jure as well as de facto stateless persons (UNHCR, 2010). Thus, it is puzzling on what ground these three states allowed their citizens to sever their nationality in order to acquire another one granted by a state that does not receive their recognition. Without benefit of evidence at present, it is hard to ascertain whether nonrecognition has an impact on these governments' decision in regard to renunciation. Nevertheless, as mentioned above, their facilitation of renunciation cannot be explained in ways other than their acceptance of Taiwan's statehood and their selective interpretation of One China Policy. Such a baffling contradiction between their publicized compliance with the One China Policy and their lack of contestation against Taiwan's sovereignty as far as renunciation is concerned is another articulation of the hypocrisy of sovereignty.

Among these three source countries, Vietnam warrants further attention. It is not only the largest source of naturalized Taiwanese citizens but it also received more than 3,000 returnees from Taiwan who became stateless (McKinsey, 2007). In 2007, the UNHCR reported the hardship endured by Vietnamese women who lost their marriage and returned to Vietnam with their children (McKinsey, 2007). Some women were able to regain their Vietnamese nationality, whereas others failed partly because of the red tape and the high fees charged by agents for the citizenship reacquisition process. While they became de jure stateless in their birth country, their children suffered de facto statelessness in Vietnam, because, as ROC citizens, their children were foreigners in Vietnam and, as such, they could not attend state school. Deprivation of education is one of the most damaging consequences that statelessness could occur to children (McKinsey, 2007, 2009, 2010). Expelled from Taiwan but unable to restore their Vietnamese nationality, 
these Vietnamese women lost not one but two nationalities. To solve the problem, the Vietnamese government later amended its nationality legislation in 2008 and allowed such women to restore their lost nationality (UNHCR, 2010: 10) (.

The Taiwanese government has not been as reconciliatory toward Vietnam as it is toward Japan. Instead, Taiwan insisted on asserting its Westphalian sovereignty and maintaining its supremacy with regard to demanding renunciation of Vietnamese citizens. In response to UNHCR reports (McKinsey 2007), the Taiwanese government issued a press release defending its position by saying that Vietnamese spouses whose marriages to Taiwanese nationals were dissolved could apply for residency in Taiwan on other statuses, one of which was being the guardian of their children. Moreover, the Taiwanese government urged the Vietnamese government to shoulder its moral responsibility and to facilitate the restoration of Vietnamese citizenship of these stateless women (Lih Pao, 2008). The Taiwanese government did not acknowledge that the requirement of renunciation was the root cause of the Vietnamese women's statelessness and their children's deprivation of public education in Vietnam. It is also surprising that neither the UNHCR nor the Vietnamese government questioned the legitimacy of Taiwan's requirement given their non-recognition of Taiwan's sovereignty.

In sum, the above investigation made it clear that by default, sovereignty of any state is hypocritical as far as nationality laws are concerned. That is, although nationality is said to be a fundamental right indispensable for human dignity, once being institutionalized, its attainment and abdication is ultimately controlled by sovereignty. Sovereignty is paradoxically endowed with the supreme authority to grant as well as to deny a human being such dignity. 
Taiwan is no exception to this paradox. In spite of their obligation to prevent statelessness and their One China Policy, Japan and Vietnam responded differently to Taiwan's requirement for marriage migrants to renounce their original citizenship, and in turn, Taiwan's selective flexibility created another layer of hypocrisy to its Westphalian sovereignty. Rejected by Japan, Taiwan turned accommodating and waived the renunciation requirement to solve the problem of a very small number of Japanese citizens. On the other hand, with Vietnam's tacit acceptance, Taiwan required nearly 70,000 Vietnamese women to renounce their Vietnamese citizenship, and when the issue of 3,000 Vietnamese women's statelessness emerged, Taiwan shifted the blame onto Vietnam. Why and how such confusing contradictions emerge between Taiwan and origin countries will require further empirical research. Suffice to say that this inconsistency is a telling indication of hypocrisy.

\section{A make-believe nationality: Household registration}

While origin states may have varying responses to Taiwan on the issue of renunciation, the PRC has been persistent in denying Taiwan's sovereignty. However, China's denial has to come to terms with the reality that Taiwan proper has been under independent jurisdiction since 1949. Thus, when Mainland Chinese women migrate and settle in Taiwan, their settlement and the granting of citizenship come under Taiwan's exclusive jurisdiction. This situation presents another case that signifies the hypocrisy of Taiwan's sovereignty.

This particular hypocrisy is rooted in the Constitutional Amendments that prolonged the Civil War legacy and fall short of recognizing both the PRC and ROC as two separate and mutually independent sovereign states. The Preamble of the Constitutional Amendments declares that the amendments are aimed at facilitating national unification. For this purpose, the 
Amendments refrain from acknowledging the PRC as a separate sovereign state but a political entity on equal footing to Taiwan (Hughes, 1999: 66; Jacobs, 2005: 36). This provision continues the unrealistic sovereignty claim to continental China as the ROC's territory and the people in the territory as ROC nationals. This 'equality' downgrades the authority of the government on either side of the Taiwan Strait to jurisdiction (tongzhiquan, 統治權) rather than sovereignty.

This outdated claim apparently cannot keep up with the fact that the interactions between Taiwan and China have greatly expanded since November 1987 when the ban on traveling to China was lifted. A pressing need was thus felt for regulating the interactions across the Taiwan Strait. Article 11 of the Constitutional Amendments thus mandates the government to by-pass the Constitution and make special laws for this purpose. Promulgated in July 1992, the Cross-Strait Relations Act is the foundation of these special laws and serves the purpose of redefining the status of PRC citizens under the legal system of Taiwan. It divides the sovereign territory of the ROC into the Mainland Area and the Taiwan Area and makes PRC citizens a special category of nationals, who are separated from the citizens of Taiwan. They are pragmatically designated as 'People of the Mainland Area,' The government was determined to enforce this categorization by other laws, such as the Employment Services Act, which was initiated for legalizing the importation of foreign workers. One of the major debates when the draft bill of the Employment Services Act was deliberated was whether the proposed law would apply to PRC citizens, since such application might imply that they were foreigners (LY 1992c: 31-33, 34). In January 1992, the legislators reached the consensus that this new law could apply (zhunyong, 準用) to PRC citizens, although they would not be regarded as foreigners (shiwei, 視為). The government 
disputed with the legislators (LY, 1992d: 6-25) and a new draft bill specifying the exclusion of its application to PRC citizens was later passed by the Legislative Yuan.

This episode showcases the insistence of the government to ensure that PRC citizens are a special kind of nationals, a distinction that is maintained by the Constitutional Court (Yeh, 2014: 16). They are distinguished from citizens born in Taiwan by their lack of household registration in Taiwan. . This is supported by Article 2 of the Cross-Strait Relations Act, which designates the household registration as a de facto nationality distinguishing the People of the Taiwan Area (ROC citizens) from the People of the Mainland Area (PRC citizens). Fundamentally, an ROC citizen is someone who holds a household registration issued in Taiwan (Rigger 2002). The household registration, thus, is appropriated as a make-believe nationality.

The necessity of maintaining a singular household registration either in Taiwan or in China is analogized as non-tolerance for dual nationality of foreign citizens. For the purpose of preventing political 'contamination' and ensuring the singular and exclusive loyalty of Taiwanese citizens, the draft bill of the Cross-Strait Relations Act proposed that a two-year consecutive residency of Taiwanese citizens in China would result in the automatic cancellation of the household registration in Taiwan and a subsequent loss of citizenship (Article 2). The rationale was that two years spent in China would weaken Taiwanese citizens' identification with Taiwan and make them susceptible to communist ideology (EY, 1990: 11-12). Although the legislators agreed with the necessity of securing exclusive loyalty toward Taiwan, they argued against the idea that two years would lead to an identity shift. Thus, the threshold was eventually increased to four years (LY, 1992a: 71; LY, 1992b: 612-614). Household registration as a makebelieve nationality was extended to apply to PRC citizens. In 2002, after the government's announcement of 'One Country on Each Side' as a conceptual framework for defining Taiwan- 
China relations (Jacobs, 2005:45), this quasi-sovereign control method was reinstated by the government's amendments to the Cross-Strait Relations Act (EY, 2002: 52-56). At the height of emotive identity politics generated by other amendments (Tseng et al., 2014), the cancellation of household registration in China was passed on 9 October 2003 as a necessary condition for PRC citizens to be eligible for ROC citizenship (LY, 2003: 287).

The singular household registration on either side of the Taiwan Strait creates a 'sovereignty effect' (Friedman, 2015) on the ambiguous relationship between Taiwan and China. Article 9 of the Cross-Strait Act stipulates that the People of the Taiwan Area are forbidden to acquire a household registration in China or obtain a PRC passport, otherwise, it will lead to automatic cancellation of their household registration in Taiwan and all citizenship rights, including political rights. Article 17 stipulates that a (PRC) Chinese spouse may be eligible for citizenship if he/she is of good character, has no criminal record, cancels household registration in China, satisfies the national interest, and has continuously resided in Taiwan for a minimum of six years.

Unlike foreign spouses whose renunciation cannot be realized without the permission of their state of origin, PRC Chinese spouses do not seem to encounter objections by local governments in China where they apply for the cancellation of their household registration. There had been cases of some local governments not permitting the cancellation unless the applicant shows proof of having obtained household registration in Taiwan (Tsai, 2012: 9). This may not cause complications since PRC citizens may submit the proof of losing their household registration in China within three months after they acquire ROC citizenship. However, if they fail to comply, their citizenship will be withdrawn (Article 31, Regulations Governing Sponsored Residency, Long-Term Residency and Settlement of People of the Mainland Area in the Taiwan 
Area). China's non-objection and Taiwan's appropriation of household registration (as an alternative to nationality) is the embodiment of the hypocrisy of Taiwan's sovereignty. This hypocrisy is verbalized by a Chinese woman I interviewed in the summer of 2009:

In China, what was cancelled by the Public Security Bureau was my household registration. [...] This is good for the Chinese government [because in their view] my household registration was not cancelled but simply being moved to Taiwan, which [they believe] is still under its sovereignty within the Chinese territory. However, the perception of the Taiwanese government was that I've lost my PRC nationality. [...] Both governments can please themselves [with what they prefer to believe]' (Interview, 18 March 2009, in Taipei).

The façade of using the household registration as an 'as if' nationality is maintained by both governments across the Strait. It meets the need of the Taiwanese state for exerting its quasi-sovereignty and asserting its independence and it also entertains the fantasy of the PRC state for One China and its rejection of Taiwan's sovereignty. The settlement of Chinese spouses has created a judicial and political site where Taiwan's quasi-sovereignty is exercised without evoking the name of sovereignty. It is this as if nationality and the necessity of substituting the household registration for nationality that highlights the hypocrisy of the sovereignty of Taiwan.

\section{Conclusion}

Employing Krasner's theory of 'organized hypocrisy' and focusing on the nationality of foreign wives, the findings of this research do not support the popular discourse that transnational migration erodes the sway of sovereignty. Instead, sovereignty has been persistently asserted in 
Taiwan's demand for foreign spouses to renounce their original citizenship. This paper asserts that Taiwan's exercise of sovereignty is organized hypocrisy particularly when such a demand can lead to statelessness for foreign spouses and the pretense of using household registration as a make-believe nationality for Chinese spouses. The hypocrisy manifests in different levels. As a de facto state, Taiwan has a responsibility to prevent statelessness. In enforcing its Westphalian sovereignty, Taiwan adopts a double standard in its policies and practices concerning nationality. It allows its citizens to have dual nationality but demands naturalized citizens to pledge singular and exclusive allegiance toward Taiwan. Furthermore, the exceptional status of Taiwan as a de facto state receiving limited external recognition renders itself to other aspects of hypocrisy with regard to renunciation. Although both adopt the One China Policy, Japan rejects Taiwan's sovereignty, whereas Vietnam seems to tacitly accept Taiwan's sovereignty. In response, Taiwan is accommodating toward Japanese citizens but shows no flexibility toward Vietnamese citizens. Taiwan's contrasting responses to Japan and Vietnam underline the discrepancy between ideals or principles and practices about mutual recognition and national sovereignty that are at the heart of international legal sovereignty and Westphalian sovereignty. When Taiwan's exercise of sovereignty caused the de jure statelessness of Vietnamese women and de facto statelessness of their children in Vietnam, it did not acknowledge that it contributed to the problem but instead shifted the blame onto the Vietnamese government for failing to restore its citizens' loss of nationality. Another aspect of hypocrisy is the make-believe nature of Taiwan's demand of cancelling the household registration in China of Chinese spouses. In this case, Taiwan's exercise of sovereignty is under the guise of being an authority of jurisdiction, which appropriates household registration as a substitute for nationality. However, the more it intends to create a sovereignty effect, the more its 'not-so-real' quality is revealed. Sovereignty has been 
characterized as a 'Janus-faced, lawless lawmaker' (Wachspress 2009: 318). The findings of this research suggest that sovereignty cannot be analyzed only as a philosophical construct but a reality that has profound socio-political and economic impact on people's everyday life.

\section{References}

Augustine-Adams K (2002) "She consents implicitly": Women's citizenship, marriage, and liberal political theory in late-nineteenth- and early-twentieth-century Argentina. Journal of Women's History 13(4): 8-30. Winter.

Batchelor CA (1995) UNHCR and issues related to nationality. Refugee Survey Quarterly 14(3): 91-112.

BBC Monitoring International Reports (2006) Vietnam restates One-China policy, opposes "independent Taiwan" - spokesman. 5 March. Available at: http://search.ebscohost.com/login.aspx?direct=trueand AuthType=ip,shiband $\underline{\mathrm{db}=e d s n b k a n d \mathrm{AN}=11030 \mathrm{~A} 1 \mathrm{ADACF} 0980 \mathrm{and} \text { site }=\text { eds-live }}$

Brown W (2010) Walled States, Waning Sovereignty. Brooklyn, NY: Zone Books.

Chamberlain JP (2015) On autonomy and migration: The politics of statelessness. At the Interface / Probing the Boundaries 89: 3-28.

Chang J-LJ (2010) Taiwan's participation in the World Health Organization: The U.S. "facilitator" role. American Foreign Policy Interests 32(3): 131-146.

Chao A (2004) Imagined modernities, transnational marriage and border control: A case study of Taiwan's “mainland brides” [現代性想像與國界管理的衝突：以中國婚姻移民女性為研究案例] (In Chinese). Taiwanese Journal of Sociology [台灣社會學刊] 32(June): 59-102.

Chao A (2005) Household registration, social welfare distribution and border control: A case study of regulating mainland spouses in Taiwan [社福資源分配的戶籍邏輯與國境管理的限制 : 由大陸配偶的入出境管控機制談起] (In Chinese). Taiwanese: A Radical Quarterly in Social Studies [台灣社會研究季刊] 59(September): 43-90.

Chen CJ (2009) Gendered borders: The historical formation of women's nationality under law in Taiwan. Positions 17(2): 289-314. 
Chen C-YJ and Yu T-L (2005) Public attitudes toward Taiwan's immigration policies [台灣民眾 對外來配偶移民政策的態度] (In Chinese). Taiwanese Sociology [台灣社會學] 10: 95-48.

Chen LT-S (2012) Stateless or belonging to Taiwan or PRC: Nationality and passport of overseas Chinese. In: Tan C-B (ed) Routledge Handbook of the Chinese Diaspora. London: Routledge, pp. 310-322.

Chen M-H (2010) Sexualized border control: The investigation of 'phony marriages' and the exclusion of Chinese migrants/sex workers [性化的國境管理：「假結婚」查察與中國移民／性 工作者的排除] (in Chinese). Taiwanese Sociology [台灣社會學]19(June): 55-105.

Cheng I (2013) Making foreign women the mother of our nation: The excluding and assimilating immigrant wives from outside. Asian Ethnicity 14(2):157-179.

Cheng I (2016) Cross-strait marriages and immigration policies. In: Shubert G (ed) Handbook of Modern Taiwan Politics and Society. London: Routledge, pp. 447-463.

Cheng I (2017a) She cares because she is a mother: The intersection of citizenship and motherhood of Southeast Asian immigrant women in Taiwan. In: Fresnoza-Flot A and Ricordeau G (eds) Gender, Migration and Citizenship: Revisiting Southeast Asian International Marriages. London: Routledge, pp.158-175

Deans P (2001) A democracy craving for recognition: A pessimistic view of the impact of democratisation on Taiwan's international status. China Perspectives 34(march-April): 3547.

De Hart B (2006a) The unity of the family? Legal perspectives on nationally mixed marriage in postwar Europe. In: Waldis B and Byron R (eds) Migration and Marriage: Heterogamy and Homogamy in A Changing World. Zurich: LIT Verlag, GmbH and Co. KG Wien, pp. 179-199.

De Hart B (2006b) The morality of Maria Toet, gender, citizenship and the construction of the nation-state. Journal of ethnic and Migration Studies 32(1): 49-68.

Epstein AL (1978) Ethos and Identity: Three Studies in Ethnicity. London: Tavistock Publications.

Executive Yuan (EY) (1990) The Draft Bill of the Act Governing Relations between People of the Taiwan Area and the Mainland Area Submitted to the Legislative Yuan. The 
Legislative Yuan General No. 1554, Initiative of Government No. 3933. [立法院議案關係文 書院總第一五五四號, 政府提案第三九三三號, 中華民國七十九年十二月五日印發, 案由: 行政院函 請審議「台灣地區與大陸地區人民關係條例草案」案] (In Chinese). 5 December.

Executive Yuan (EY) (2002) The Draft Bill of the Act Governing Relations between People of the Taiwan Area and the Mainland Area Submitted to the Legislative Yuan. The Legislative Yuan General No. 1554, Initiative of Government No. 8786. [立法院議案關係文 書院總第一五五四號，政府提案第八七八六號，中華民國九十一年十月十六日印發，案由：行政院函 請審議「台灣地區與大陸地區人民關係條例草案」案] (In Chinese).16 October.

Feinberg M (2006) Elusive Equality : Gender, Citizenship, and the Limits of Democracy in Czechoslovokia, 1918-1950. Pittsburgh, PA: University of Pittsburgh Press.

Friedman SL (2015) Exceptional States: Chinese Immigrants and Taiwanese Sovereignty. Oakland, CA: University of California Press.

Grossman, A. (2001). Nationality and the Unrecognised State. International \& Comparative Law Quarterly, 50(4): 849-876.

Gu W (1995) Conflicts of Divided Nations: the Cases of China and Korea. Wesport, CT: Praeger.

Ho PSC (2006) The impact of the U.N. fish stocks agreement on Taiwan's participation in international fisheries fora. Ocean Development and International Law 37(2): 133-148.

Hsiao H-P (2010) The Negotiation and Performance of Cultural Citizenship by Female Japanese Spouses in Taiwan [文化公民權協商與展演：以在台日籍女性配偶的生活為例] (In Chinese). Master’s Degree dissertation. National Sun Yat-Sen University, Kaohsiung.

Hsiao MH-H (2003) Taiwan and Southeast Asia: Go South Policy and Vietnamese Brides. Taipei: Center for Asia-Pacific Area Studies, Academia Sinica.

Huang L-L (2006) A world without strangers? Taiwan's new households in the nexus of China and Southeast Asia relations. International Development Planning Review 28 (4): 447-474. 
Huang YL and Wang $\mathrm{CH}$ (2013) Chinese question in the Olympic movement: From the perspective of Taiwan. International Journal of the History of Sport 30(17): 2052-2068.

Huang Y-H and Liaw B (2012) Taiwan's economic diplomacy in Vietnam from the 1990s to the early twenty-first century. East Asia: An International Quarterly 29(4): 355-376.

Hughes C (1999) Taiwan and Chinese Nationalism: National Identity and Status in International Society. London: Routledge.

Jacobs B (2005) 'Taiwanisation' in Taiwan's politics. In: Makeham J and Hsiau A-C (eds) Cultural, Ethnic, and Political Nationalism in Contemporary Taiwan. Bentuhua. New York, NY: Palgrave Macmillan, pp.7-54.

Kawaguchi D and Lee S (2012) Brides for Sale: Cross-Border Marriages and Female Immigration. Discussion Paper series, Forschungsinstitut zur Zukunft der Arbeit, No. 6458. Available at: http://nbn-resolving.de/urn:nbn:de:101:1-201208065409

Kingston, LN (2013). “A Forgotten Human Rights Crisis": Statelessness and Issue (Non) Emergence. Human Rights Review, 14(2): 73-87.

Krasner S (1999) Sovereignty: Organized Hypocrisy. Princeton, NJ: Princeton University Press.

Kuo Y-H (2011) Subversions of the social hierarchy: Social closure as adaptation strategy by the female marriage migrants of Taiwan. Journal of Comparative Research in Anthropology and Sociology 2(1): 85-101.

Lan P-C (2008) Migrant women's bodies as boundary markers: Reproductive crisis and sexual control in the ethnic frontiers of Taiwan. Signs 33(4): 833-861.

Lee T-H (1999) Understanding Taiwan: Bridging the perception gap. Foreign Affairs 78(6): 914.

Legislative Yuan (LY) (1992a) Record of Floor Meeting. 26 June. (院會紀錄) (In Chinese). The Official Gazette of the Legislative Yuan（立法院公報第八十一卷五十二期) 81(52): 47-77.

Legislative Yuan (LY) (1992b) Record of the Sixth Joint Deliberation Meeting of the Draft Bill of the Act Governing the Relations between the People of Taiwan Area and Mainland Area by the Committees of Home Affairs, Judiciary, and Organic Laws and Statutes (EightyNinth Session of the Frst Legislative Yuan). 23 June (In Chinese). The Official Gazette of the Legislative Yuan [立法院公報第八十一卷二十六期] 81(26): 607-653. 
Legislative Yuan (LY) (1992c) Record of Floor Meeting [院會紀錄]. 9 January (In Chinese). The Official Gazette of the Legislative Yuan [立法院公報第八十一卷第五期] 81(5): 26-63.

Legislative Yuan (LY) (1992d) Record of Floor Meeting[院會紀錄]. 14 January (In Chinese). The Official Gazette of the Legislative Yuan [立法院公報第八十一卷 第六期] 81(6): 6-25.

Legislative Yuan (LY) (1998a) Minutes of the First Joint Deliberation Meeting of the Draft Bill of the Immigration Act by the Committees of Home and Frontier Affairs, Foreign and Overseas Chinese Affairs, Transport and Communication, and Judicial Affairs, the Sixth Session of the Third Legislative Yuan. 2 November (In Chinese) The Legislative Yuan Gazette [立法院公報第八十七卷第四十五期] 87(45): 183-232.

Legislative Yuan (LY) (1998b) Minutes of the Second Joint Deliberation Meeting of the Draft Bill of the Immigration Act of the Committees of Home and Frontier Affairs, Foreign and Overseas Chinese Affairs, Transport and Communication, and Judicial Affairs (Sixth Session of the Third Legislative Yuan). 16 December (In Chinese). The Legislative Yuan Gazette [立法院公報第八十七卷第五十期] 87(50): 249-305. Legislative Yuan (LY) (2003) Record of Floor Meeting [院會紀錄]. 9 October (In Chinese). The Official Gazette of the Legislative Yuan [立法院公報第九十二卷 第四十一期] 92(41): 284-327.

Legislative Yuan (LY) (2016) Minutes of the $9^{\text {th }}$ Plenary Meeting of the Committee of Home Affairs, the $1^{\text {st }}$ Session of the $9^{\text {th }}$ Legislative Yuan. 18 April (In Chinese). The Legislative Yuan Gazette [立法院公報 第 105 卷第 29 期 委員會紀錄] 105(29): 1-80.

Lih Pao (2008) Vietnamese Spouses Who Lost Marriage May Restore Nationality. 11 March (In Chinese). Available at: http://www.Lihpao.com/?action-viewers-itemid-6795

Liberty Times (2007). Cambodian Brides May Become Statelessness. 4 March (In Chinese). Available at: news.ltn.com.tw/news/politics/paper/118474

Lu C-Y (2000) Politics of foreign labor policy in Taiwan. Journal of Asian and African Studies 35(1): 113-131.

McKinsey K (2007) Divorce leaves some Vietnamese women broken-hearted and stateless. UNHCR. 14 February. Available at: http://www.unhcr.org/45d324428.html

McKinsey K (2009) Viet Nam sets the pace for Asia with new law to prevent statelessness. UNHCR. 1 July. Available at: http://www.unhcr.org/news/latest/2009/7/4a4b809d9/viet$\underline{\text { nam-sets-pace-asia-new-law-prevent-statelessness.html }}$ 
McKinsey K (2010) Preventing Statelessness: Southeast Asian Countries Share Lessons. UNHCR. 29 October. Available at: http://www.unhcr.org/news/latest/2010/10/4ccae1009/preventing-statelessness-southeastasian-countries-share-lessons.html

Ministry of the Interior (MoI) (2015) Statistical Yearbook of Interior (Numbers of the Acquisition of ROC Nationality). Available at: http://sowf.moi.gov.tw/stat/year/list.htm

Morello F (1966) The International Legal Status of Formosa. The Hague: Martinus Nijhoff.

National Security Council (NSC) (2006) National Security Report (In Chinese). Taipei: National Security Council.

National Immigration Agency (NIA) (2017) Numbers of Foreign Spouses and Mainland Spouses (Including Spouses from Hong Kong and Macao. 18 January (In Chinese). Available at http://www.immigration.gov.tw/ct.asp?xItem $=1325434 \& c t N o d e=29699 \& \mathrm{mp}=1$

Peng S-Y (1997). Economic relations between Taiwan and Southeast Asia: A review of Taiwan's Go South policy. Wisconsin International Law Journal 16(3): 639-660.

Rigger S (2002) Nationalism versus citizenship in the Republic of China on Taiwan. In:

Goldman M and Perry EJ (eds) Changing Meanings of Citizenship in Modern China.

Cambridge: Harvard University Press, pp. 353-372.

Roy D (2003) Taiwan: A Political History. Ithaca, NY: Cornell University Press.

Scott JB (1929) Problems of nationality: International status of married women. Advocate of Peace through Justice 91(3): 137-140.

Sheu Y-H (2007) Full responsibility with partial citizenship: Immigrant wives in Taiwan. Social Policy and Administration 41(2): 179-196.

Studer B (2001) 'Citizenship as Contingent National Belonging: Married Women and Foreigners in Twentieth-Century Switzerland'. Gender \& History 13(3): 622-654 November

The China Post (2011) Taiwan recalls envoy to Philippines. 11 February. Available at: http://www.chinapost.com.tw/asia/philippines/2011/02/08/290282/Taiwan-recalls.htm 
Tsai C-C (2012) An analysis on the equality of naturalisation regulations for foreign spouses and mainland spouses and a critique on the protection of their rights and lives in Taiwan [論外籍 及大陸配偶在臺人籍規範之權益衡平性一兼論兩者在臺生活權益保障之現況及檢討] (In Chinese). Paper presented at the Conference on Population Movement and Law Enforcement, 13 November, Taipei.

Tsai C-J (2008) An Analysis on Basic Family Rights of Foreign Spouses and Expulsion: A Case Study of the Verdict of Su 20581 by Taipei High Administrative Court in 2006 [自外籍配偶 家庭基本權之保障論驅逐出國處分 - 評臺北高等行政法院95年度訴字第02581號判決] (In Chinese). Paper presented at the Conference on Border Security and Population Movement, 8 December, Taipei.

Tsai M-C (2011) 'Foreign brides' meet ethnic politics in Taiwan. International Migration Review 45(3): 243-268.

Tseng W-C (1999) An Analysis on the Immigration Act [入出國移民法釋論] (In Chinese). Taipei: Cheng Chung.

Tseng Y-F and Komiya Y (2011) Classism in immigration control and migrant integration. In: Ngo T-W and Wang H-Z (eds) Politics of Difference in Taiwan.. London: Routledge, pp. 98-115.

Tseng Y-C, Cheng I and Fell D (2014) The politics of the mainland spouses' rights' movement in Taiwan. In: Fell D, Chiu K-F and Lin P (eds) Migration to and from Taiwan. London: Routledge, pp. 205-226.

Tucker NB (2011) Strait Talk: United States-Taiwan Relations and the Crisis with China. Cambridge, MA: Harvard University Press.

UNHCR (2010) Good Practices: Addressing Statelessness in South East Asia. Report of the Regional Expert Roundtable on Good Practices for the Identification, Prevention and Reduction of Statelessness and the Protection of Stateless Persons in South East Asia, Bangkok, 28 to 29 October. At http://www.unhcr.org/protection/statelessness/4d7de47f9/goodpractices-addressing-statelessness-south-east-asia-report-regional.html

Van Waas L (2012) Fighting statelessness and discriminatory nationality laws in Europe. European Journal of Migration and Law 14: 243-260.

Wachspress M (2009) Rethinking sovereignty with reference to history and anthropology. International Journal of Law in Context 5(3): 315-330. 
Wang H-Z (2008) Taiwanizing female immigrant spouses and materializing differential citizenship. Citizenship Studies 12(1): 91-106.

Wang H-Z (2011) Immigration trends and policy changes in Taiwan. Asian and Pacific Migration Journal 20(2): 169-194.

Wu Y-T (2008) Taiwan international family in a difficult situation of the legislation. Taiwan International Law Quarterly 5(1): 51-82.

Xinhua News Agency (2002) Indonesian consulate general in HK reiterates One-China policy. Available at: http://www.china.org.cn/english/international/39718.htm

Yang C-J and Chien H-C (2010) Could Taiwan be included in UNFCCC negotiations? Climate Policy (Earthscan) 10(3): 317-321.

Yang W-Y and Lee P-R (2009) The citizenship dilemma of mainlander spouses in Taiwan: The conspiracy of nationalism and patriarchy [大陸配偶的公民權困境一國族與父權的共謀] (In Chinese). Taiwan Democracy Quarterly [臺灣民主季刊] 6(3): 47-86.

Yeh C-H (2014) The legal status of foreign spouse - from the aspects of entry, permanent stay, and naturalization [論外籍配偶的法律地位一以入境、居留與歸化為中心] (In Chinese). Taiwan International Law Quarterly [台灣國際法季刊] 11(3): 7-26.

Yuval-Davis N and Anthias F (1989) Woman-Nation-State. London: Macmillan. 